\title{
Special years for International Orthopaedics
}

\author{
Marko Pecina $\cdot$ Anthony Hall
}

Received: 24 November 2009/Published online: 4 December 2009

(C) Springer-Verlag 2009

\section{Why special?}

The years 2009 to 2010 mark a milestone in the 33 year existence of our journal, as the moment that the Impact Factor surpassed 1.0. The two-year Impact Factor for 2008 was 1.235 and the five-year Impact Factor was even better at 1.302.

In addition, with the full cooperation of Springer, our publishers, we have managed to solve the problem of the huge backlog of papers accepted for publication in our journal. In 2009, six issues of International Orthopaedics were published as usual but the number of pages and number of articles per issue were doubled, that is to say that more than 300 articles were published on over 1,750 pages. During 2009 our subscribers had to endure so-called "thick issues", but from January 2010 we will publish eight issues per year which should appear in January, February, March, April, June, August, October and December. This will reduce the time for the publication of an article online to the publication in printed form to between ten months and one year. The time from reception of an article to acceptance/ rejection is about one month and from acceptance to publication online a further month.

We also plan to improve the appearance of the journal by upgrading the cover and the layout of the contents page. We hope that this improved graphic design will meet with the approval of our readers. At the same time, the Editorial Board intends to improve the content of the journal and will accept

\section{Pecina $(\square)$}

Department of Orthopaedic Surgery, University of Zagreb,

Salata 6,

Zagreb 10000, Croatia

e-mail: marko.pecina@zg.t-com.hr

\section{A. Hall}

Northacre Cottage,

Chandler's Green, Mattingley RG27 8LH, UK

e-mail: a.hall@ajamh.co.uk only good papers through stringent selection by reviewers. To achieve this we have increased the number of corresponding members of the Editorial Board and, to acknowledge the tremendous contribution of our excellent reviewers, their names will be published in the February issue .

Not only are these special years for us but we also face a unique situation in our journal: As the official journal of SICOT we publish articles from more than 50 countries around the world including articles from authors in developing countries. This creates a challenge in balancing the interests of our members, the authors and readers, with the maintenance of a high Impact Factor for the journal. Statistics help to explain the situation: Among the most requested articles from our journal between January and May 2009 were those of Changulani et al. [2], Karuppiah et al. [4] and Rayan et al. [5]. At the same time the three most cited articles as regards the 2008 Impact Factor of the journal were the articles of Bilic et al. [1], White et al. [6] and Francheschi et al. [3]. Clearly these are two different groups of articles, but both are very valuable for the speciality of orthopaedic surgery. Our intention is to continue to publish a full variety of articles but only good papers will be accepted. The Impact Factor is important but it is not the only goal of our journal. We have others; for example, in 2006 we introduced special issues, where one member of our editorial team with an interest in a specialist branch of orthopaedics is invited to assemble a selection of articles from experts around the world. We published a tumour issue edited by Miklos Szendroi and the following year a bone biology issue edited by Marko Pecina and Slobodan Vukicevic. We intend to continue this endeavour, which we believe broadens the appeal of our journal. Issue number 2, to be published in February 2010, will address the subject of "Osteotomy around the knee" and will be edited by Thami Benzakour, who has assembled experts 
from around the world to provide a comprehensive review of the subject.

A policy of constant development is essential in the world of modern, international, scientific publication and the editorial team at International Orthopaedics will continue in their efforts to keep us in the forefront of this endeavour. These goals can only be achieved by mutual cooperation, and the intention of this editorial is to stimulate all of us to participate in this project.

\section{References}

1. Bilić R, Simić P, Jelić M, Stern-Padovan R, Dodig D, van Meerdervoort HP, Martinovic S, Ivanković D, Pećina M, Vukičević S (2006) Osteogenic protein-1 (BMP-7) accelerates healing of scaphoid non-union with proximal pole sclerosis. Int Orthop 30:128-134

2. Changulani M, Okonkwo U, Kesovani T, Kalarijah Y (2008) Outcome evaluation measures for wrist and hand-which one to choose? Int Orthop 32(1):1-6

3. Franceschi F, Longo UG, Ruzzini L, Papalia R, Rizzello G, Denaro $\mathrm{V}$ (2007) To detach the long head of the biceps tendon after tenodesis or not: Outcome analysis at the 4-year follow-up of two different techniques. Int Orthop 31(4):537-545

4. Karuppiah SV, Banaszkiewicz PA, Ledingham WM (2008) The mortality, morbidity and cost benefits of elective total knee arthroplasty in the nonagenarian population. Int Orthop 32 (3):339-343

5. Rayan F, Bhousle S, Shukla DD (2009) Clinical, MRI, and arthroscopic correlation in meniscal and anterior cruciate ligament injuries. Int Orthop 33(1):129-132

6. White PA, Vaccaro AR, Hall JA, Whang PG, Friel BC, McKee M (2007) Clinical applications of BMP-7/OP-1 in fractures, nonunions and spinal fusions. Int Orthop 31(6):735-741 